\title{
How Does CEO Career Origin Influence Firm's Risk-Taking?
}

\author{
Candra Chahyadi \\ Eastern Illinois University \\ Pamitra Wineka \\ University of Illinois at Urbana-Champaign
}

Does CEO career origin matter for corporate risk-taking? Is the level of corporate risk-taking determined by firm characteristics or by CEO personal/compensation characteristics? Using 3,006 CEO turnover data between 1992 and 2010, we find that outsider CEOs make more risky investment decisions than insider CEOs. After controlling for compensation sensitivity variables, we find that outsider CEOs are more risk-taking than insider CEOs. The board of directors may hire outsider CEOs because of the risk-taking reason. Our results also suggest that the CEO compensation structure difference is not the reason why outsider CEOs take more risk than insider CEOs.

Keywords: Executive Turnover; Outsider-Insider CEO; Risk Taking.

\section{INTRODUCTION}

How much does a CEO career origin matter for corporate risk-taking? Is the level of corporate risktaking determined by firm characteristics (such as firm size or past stock returns) or by CEO personal/compensation characteristics or by the combination of the two types of the aforementioned characteristics? If risk-taking is somehow influenced by CEO characteristics, can firms incentivize their CEOs to take more risks? How much financial incentives do risk-taking CEOs need to take more risks? These are some important questions whose answers are not easily available because the causal relation between CEO and firm risk-taking is complex and ambiguous. Finding answers to these questions is crucial because level of risk-taking, to some extent, positively affects the value of the firm and by understanding the causal relation (or lack thereof) between CEO characteristics and firm risk-taking, we can find more efficient and cost-effective ways to maximize firm value. The novel contribution of this paper is to establish the relation between a CEO career origin and corporate risk-taking and to explain why firms are now more likely to hire an outsider candidate to fill their vacant CEO positions than before.

One possible way that a CEO is related with firm risk-taking is through CEO compensation, especially through the equity-based compensation. Equity-based compensation is an important mechanism that firms use to align interests of managers and shareholders. Bebchuk and Grinstein (2005) document the increasing occurrence of equity-based compensation practice since 1993. The proliferation of equity-based compensation however presents a different kind of agency problem between shareholders and managers regarding the optimal level of firm risk-taking. Equity-based compensation gives managers incentives to work harder but on the other hand, this compensation structure may result in an undesirable 
outcome which is that most managers, whose wealth now is concentrated mostly in the company stock, will less likely to invest in risky projects in order to maintain the value of his undiversified wealth. Many studies on corporate risk-taking document how executive compensation affects corporate risk-taking and find that equity-based compensation encourages CEOs to take more risks. ${ }^{1}$ Coles, Daniel, and Naveen (2006) show that CEOs whose compensation is more sensitive to the firm's volatility (CEOs with higher vega) are more likely to make more risky investment decisions.

Another possible link connecting CEO and firm risk-taking is through CEO's personal risk-taking preference. This growing branch of literature includes the study of Bertrand and Schoar (2003) who establish the relation between manager's personal characteristics and corporate behavior and performance. Malmendier and Tate (2005) establish a relation between managerial overconfidence and corporate investment decisions. They find evidence that overconfident CEOs tend to overinvest. Frank and Goyal (2009) find that CEO fixed effect matters in the choice of corporate leverage, both in the level of leverage and also in the leverage adjustment speed. They also argue that the CEO fixed effect is a first order effect in corporate leverage. Using a sample of manufacturing and technology firms, Galasso and Simcoe (2011) find that overconfident CEOs are more willing to invest in more risky projects and to lead their firms to a change in direction. An interesting paper by Cain and McKeon (2011) finds that CEOs with high personal risk-taking (represented by CEOs who possess small airplane pilot license) increase firm's overall risk and those CEOs are associated with value increasing acquisitions. Cronqvist, Makhija, and Yonker (2012) find that CEO's personal leverage is positively correlated with their firms' choice of capital structure. In other words, they find that CEOs with more conservative personal leverage (those with lower mortgage) are more likely to implement more conservative capital structure for their firms.

Firms hire their CEOs either from outside of the firm (outsider CEO) or promote a senior executive from within the firm (insider CEO). Murphy and Zabojnik (2007) document that although CEO turnovers are still dominated by insider CEOs, firms are more likely to fill their CEO positions through external hires than through internal promotions. ${ }^{2}$ The board of directors is more likely to hire outside CEOs when the firm struggles and needs a change in direction. Ferris, Wei, and Zhang (2007) find that in general, firms that perform poorly hire a new CEO from outside of the company while firms that perform better hire a new CEO from inside of the company. They also find that outsider CEOs are paid more than insider CEOs and mainly through incentive pay, which is consistent with findings of Murphy (2002).

Unfortunately, there is not much explanation why firms are more likely to hire outsider CEOs now. ${ }^{3}$ It is a puzzling phenomenon because outsider CEOs command higher compensation than insider CEOs and hiring outsider CEOs could discourage senior executives in the firm to do well. The CEO position is usually viewed as the ultimate reward for a senior executive who does well. If the board removes the possibility that a well performing executive could become a CEO, the board does not provide the firm senior executives with the incentives to do well. Thus, if the board still hires outsider CEOs (a practice that requires higher financial investments and consequently presents disincentive for senior executives to do well), then there must be some benefits that outweigh the aforementioned costs.

It is reasonable to think that firms hire outsider CEOs because they produce better performance than insider CEOs. However, this argument is not in consistent with findings of Zhang and Rajagopalan (2010). They find that outsider CEOs outperform insider CEOs in the early part of their tenure and significantly underperform insider CEOs in the long run. Therefore, considering the higher costs to hire outsider CEOs, it is perplexing why firms hire outsider CEOs.

In this paper, we examine how a CEO career origin affects firm risk-taking and whether the reason the board of directors hires their new CEOs from outside of the firm is because of the new CEO's personal risk-taking preference.

We find that outsider CEOs make more risky investment decisions (invest more in R\&D, invest less in capital expenditures, and use more leverage) than insider CEOs. One can argue that outsider CEOs take more risks because of their compensation structure has more equity-based portion and that kind of compensation structure encourages CEOs to take more risk. ${ }^{4}$ However, after controlling for compensation sensitivity variables such as delta and vega, we find that outsider CEOs are still significantly more risktaking than insider CEOs. Our results suggest that outsider CEOs are more risk-taking than insider CEOs 
and the board of directors, despite the higher costs of hiring outsider CEOs, may very well hire outsider CEOs because of the risk-taking reason. Our results also suggest that the CEO compensation structure difference (between outsider and insider CEOs) is not the reason why outsider CEOs take more risk than insider CEOs.

In addition to examining the relation between CEO career origin and the level of the firm risk-taking, we also examine the relation between $\mathrm{CEO}$ career origin and the change in the firm risk-taking years after the CEO turnover. We find that on average, outsider CEOs increase the normalized R\&D ratio by $1.77 \%$ in the four year period (from one year before the CEO turnover to three years after the turnover), while the insider CEOs increase the normalized R\&D ratio only by $0.63 \%$ during the same time period. This also helps explain why the board is more likely to hire outsider CEOs when the firms struggle.

Our paper contributes to the CEO turnover and corporate risk-taking literature in three different ways. First, we show that a CEO career origin matters in corporate risk-taking and we extend the literature on the relation between CEO personal characteristic and corporate risk-taking. Second, we provide an alternative explanation as to why firms hire more outsider CEOs now than before. We argue that outsider CEOs do not make more risky investment decisions because of their compensation structure but they make more risky investment decisions because they are more risk-taking than insider CEOs and that may be the reason firms hire more outsider CEOs now than before. Third, we find mixed results about the relation between a CEO career origin and corporate risk-taking. Interestingly outsider CEOs increase the risk of the firm by investing more in $\mathrm{R} \& \mathrm{D}$ and less in capital expenditure, but not through increased leverage.

The rest of the paper continues as follows. In section 2, we describe our data collection and how we construct our main variables, including the CEO and firm characteristic variables. Section 3 presents all the results and section 4 concludes.

\section{DATA AND SAMPLE DESCRIPTION}

We construct our sample using CEO data from the Standard \& Poor's Execucomp database between 1992 and 2010. ${ }^{5}$ We identify a CEO if an executive has a title of "CEO" (i.e., if the Execucomp's "titleann" equals "CEO" or "Chief Executive Officer" or "Principal Executive Officer") and if the executive is clearly identified as a CEO by Execucomp (when Execucomp's CEO identifier "ceoann" equals "CEO"). Following Coles, Daniel, and Naveen (2006), we also include executives who are not identified by Execucomp as CEOs but they actually assume the CEO position. We exclude utilities firms (SIC 4900-4999) and financial services firms (SIC 6000-6999) from our sample. We obtain 24,649 CEOyear observations during this time period.

As we are interested in finding how a CEO career origin affects firm risk-taking, we furthermore search for CEO turnovers that took place during this time period and classify the new CEOs into 2 categories: insider CEOs and outsider CEOs. We define insider CEO as a CEO who is promoted from within the company or if the new CEO had worked for the company at least 1 year before he was appointed as the new CEO. We define outsider CEO as a new CEO who is hired from outside the company or if the new CEO had only worked for the company for less than 1 year before he was appointed to be the new CEO. We then construct a dummy variable, OUTSIDER, which equals 1 for outsiders and 0 for insiders. After excluding all interim CEOs, we find 3,006 CEO turnovers within this time period (among those turnovers, there are 2,212 insider CEOs and 794 outsider CEOs).

We also break down the CEO turnovers by year and by industry. The industry classification we use is based on the SIC codes and the classification is done as follows: mining and construction (1000-1999, excluding 1300-1399), food (2000-2111), textiles and printing (2200-2799), chemicals and pharmaceuticals (2800-2899), extractive (2900-2999, 1300-1399), durable manufacturers (3000-3999, excluding 3570-3579 and 3670-3679), computers (7370-7379, 3570-3579, 3670-3679), transportation (4100-4799), retail (5000-5999), services (7000-8999, excluding 7370-7379) and other (000-0999, 90009999). Utilities (4900-4999) and financial services (6000-6999) are excluded from the sample. 
We collect CEOs' personal data such as age and gender, the CEO compensation data such as salary, bonus, and equity compensation. We create the $\mathrm{CEO} /$ founder dummy, which takes a value of 1 if a $\mathrm{CEO}$ is also the founder of the company and 0 otherwise. We find 203 CEOs who are also the founders of their firms. We create the $\mathrm{CEO} /$ chairman dummy, which takes a value of 1 if a $\mathrm{CEO}$ is also the chairman of the board and 0 otherwise. We find 1,604 CEOs who are also the chairman of the board.

For the accounting data, we collect data from Compustat database over the same time period (19922010). The accounting data are deflated to constant 2000 dollars using the GDP deflator and winsorized at the $0.50 \%$ level at both tails to minimize the effect of outliers and misrecorded data. Folowing Coles, Daniel, and Naveen (2006), we use three risk-taking variables: (1) $R \& D$, defined as the ratio of research and expenditures expenses divided by assets (2) CAPEX, defined as the ratio of net capital expenditures (capital expenditures minus sales of property, plant, and equipment) divided by assets (3) LEVERAGE, defined as the ratio of long term debt plus debt in current liabilities divided by assets. For independent variables, we use the OUTSIDER dummy variable and control variables (firm characteristic variables and compensation sensitivity variables like delta and vega). For personal CEO characteristics, we collect age, tenure, sex, and two dummy variables: the chairman and founder dummies. The chairman dummy takes a value of 1 if the CEO is also the chairman of the board in that year and 0 otherwise. The founder takes a value of 1 if the CEO is the founder of the company. For compensation variables, we calculate delta and vega. Delta is the change in the dollar value of the CEO's wealth for one percentage point change in the company's stock price while vega is defined as the change in the dollar value of the CEO's wealth for a 0.01 change in the annualized standard deviation of stock returns. To calculate delta and vega, we follow Guay (1999) and Core and Guay (2002). We present the summary statistics of our variables in table 1. 


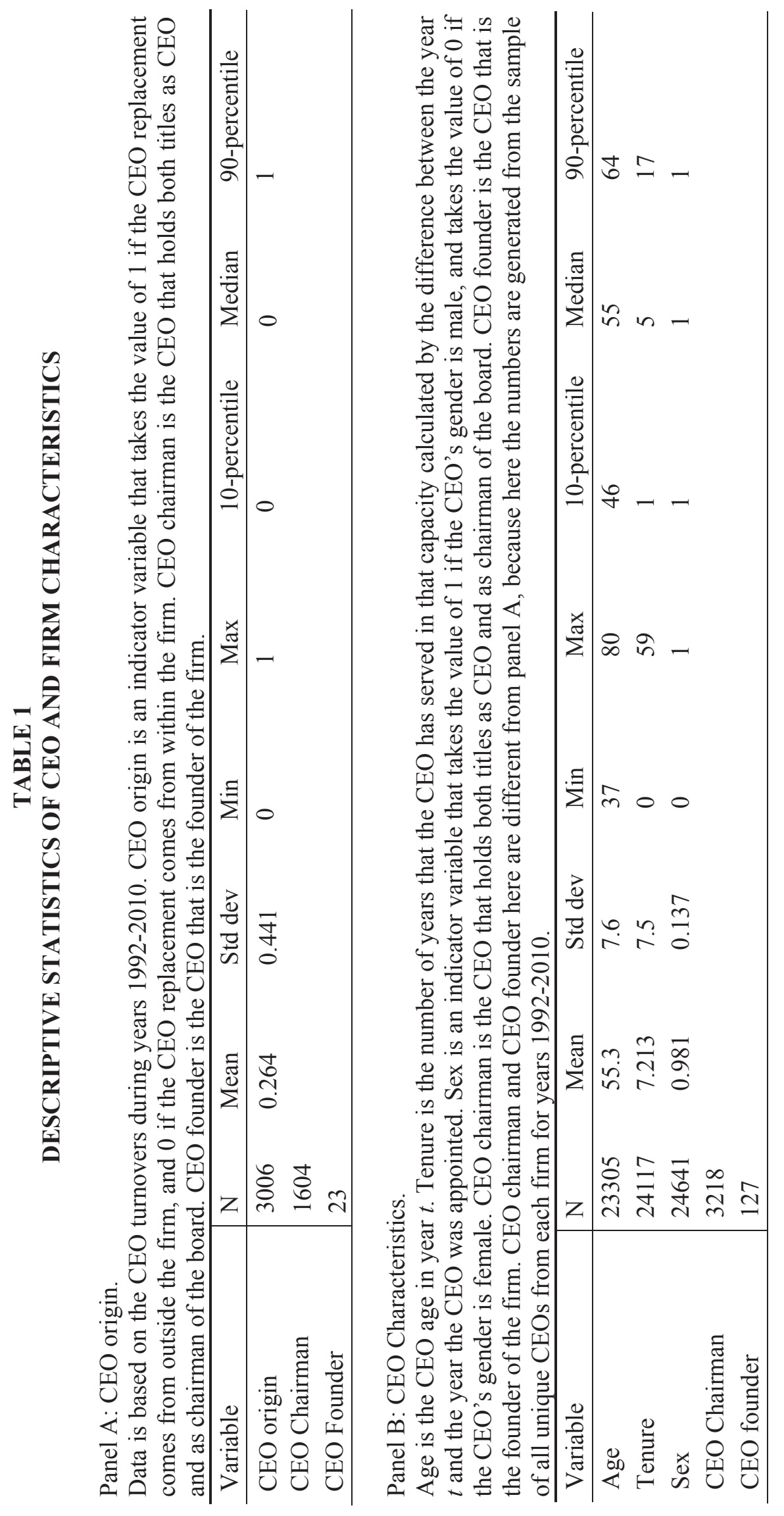

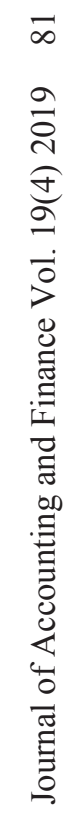




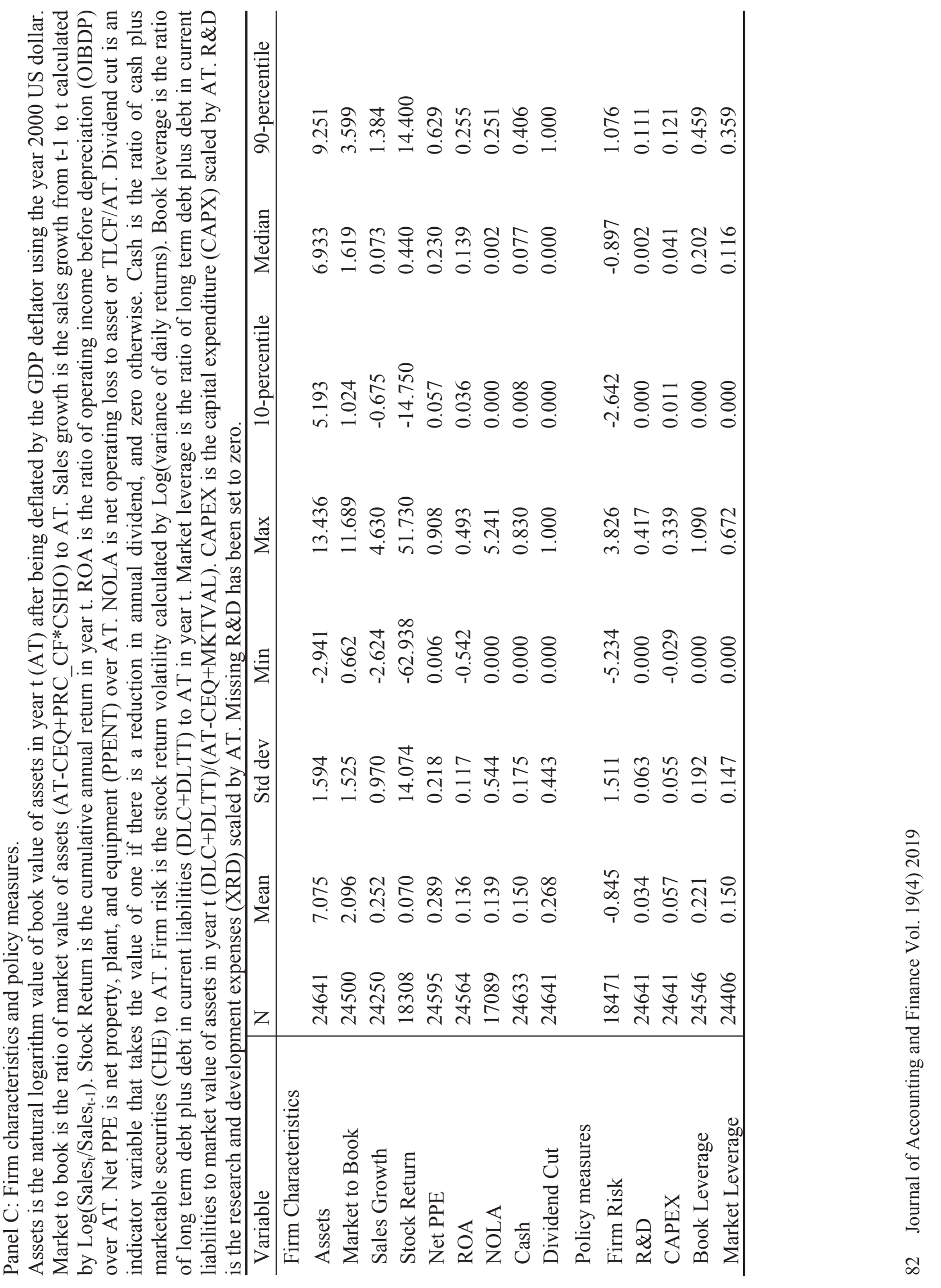




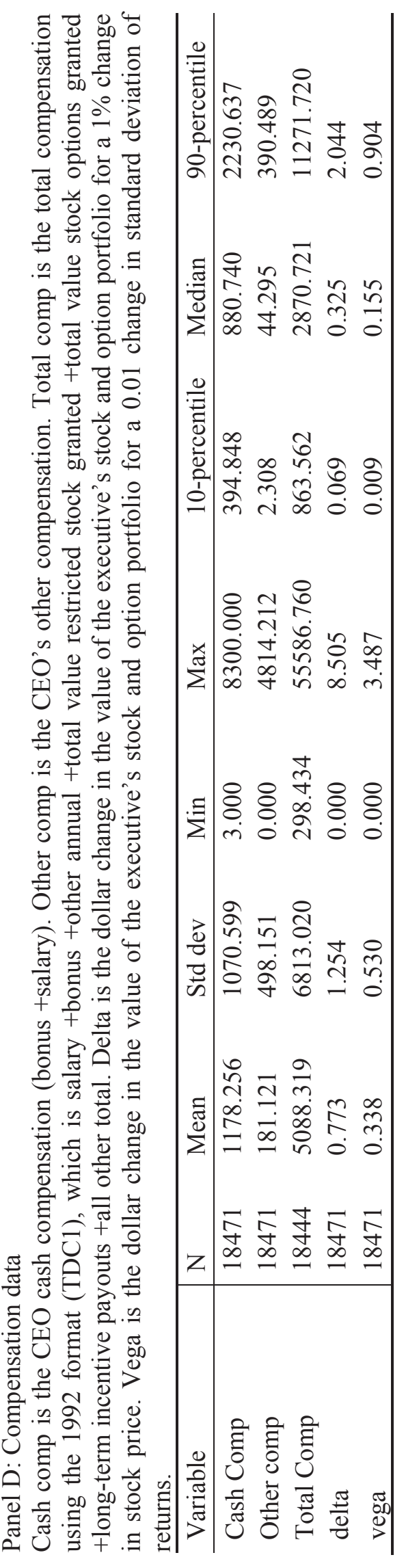




\section{RESULTS}

\section{Mean Difference Test}

We test the mean difference of risk-taking measures (such as R\&D, capital expenditure, book value of leverage, and market value of leverage) implemented by outsider and insider CEOs ten years after the CEO turnover. We present the results in table 2.

TABLE 2

\section{CEO RISK-TAKING MEASURES}

Data consist of all the CEOs and the firms from 1992-2010 obtained from Execucomp and Compustat. Year represents the CEO's years in office (e.g year=1 means the first year of becoming $\mathrm{CEO}$, year $=2$ means the second year of becoming CEO, and so on). Outsider and insider respectively are the number of data of outsider and insider CEOs. SE is the standard error obtained in the calculation. DF alternative is derived by finding the minimum between outsider and insider or min(outsider,insider). Variable $t$ is the $t$-statistics value. Variables $p$-val two-tail and $p$-val one-tail are the $p$-values calculated with the two-tail and one-tail probabilities of $t$ respectively, for the given value of DF. Each variable are used for the purposes of statistical significance testing.

Panel A: R\&D spending of CEOs.

The null hypothesis used is $\mathrm{H}_{0}: \overline{X_{\text {out }}}=\overline{X_{\text {ln }}}$, for the two-tail test and $\mathrm{H}_{0}: \overline{X_{\text {out }}} \geq \overline{X_{\text {ln }}}$ for the one-tail test, where $\overline{X_{\text {out }}}$ and $\overline{X_{\iota n}}$ are the mean of $\mathrm{R} \& \mathrm{D}$ expenditure of outsider replacement CEOs and insider replacement CEOs respectively.

\begin{tabular}{l|lllllll}
\hline Year & Outsider & Insider & $\mathrm{SE}$ & $\begin{array}{l}\mathrm{DF} \\
\text { alternative }\end{array}$ & $\mathrm{t}$ & $\mathrm{p}$-val two-tail & $\mathrm{p}$-val one tail \\
\hline 1 & 1659 & 3822 & 0.0021 & 1658 & -8.2551 & 0.0001 & 0.0001 \\
2 & 1249 & 3160 & 0.0024 & 1248 & -7.7713 & 0.0001 & 0.0001 \\
3 & 920 & 2640 & 0.0028 & 919 & -6.8482 & 0.0001 & 0.0001 \\
4 & 686 & 2109 & 0.0032 & 685 & -6.3010 & 0.0001 & 0.0001 \\
5 & 508 & 1638 & 0.0035 & 507 & -6.6890 & 0.0001 & 0.0001 \\
6 & 356 & 1261 & 0.0043 & 355 & -5.4885 & 0.0001 & 0.0001 \\
7 & 260 & 957 & 0.0052 & 259 & -5.6257 & 0.0001 & 0.0001 \\
8 & 200 & 731 & 0.0058 & 199 & -5.3803 & 0.0001 & 0.0001 \\
9 & 131 & 552 & 0.0064 & 130 & -4.2380 & 0.0001 & 0.0001 \\
10 & 88 & 431 & 0.0073 & 87 & -3.5553 & 0.0006 & 0.0003 \\
\hline
\end{tabular}

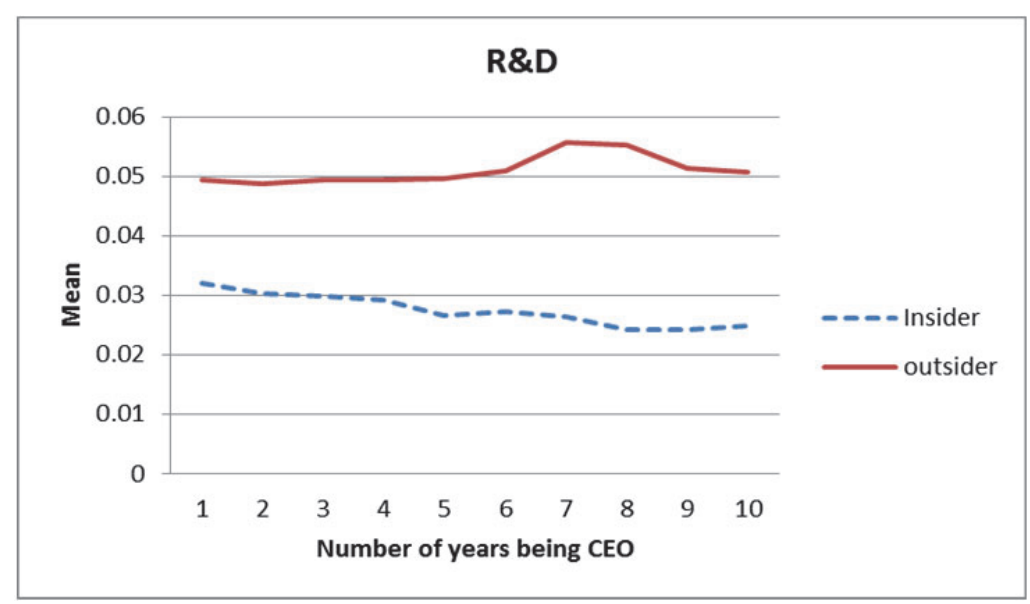

84 Journal of Accounting and Finance Vol. 19(4) 2019 
Panel B: CAPEX of CEOs.

The null hypothesis used is $\mathrm{H}_{0}: \overline{X_{\text {out }}}=\overline{X_{\text {ln }}}$, for the two-tail test and $\mathrm{H}_{0}: \overline{X_{\text {out }}} \geq \overline{X_{\text {ln }}}$ for the one-tail test, where $\bar{X}_{\text {out }}$ and $\overline{X_{l n}}$ are the mean of CAPEX of outsider replacement CEOs and insider replacem 'ent CEOs respectively.

\begin{tabular}{l|lllllll}
\hline Year & Outsider & Insider & SE & $\begin{array}{l}\text { DF } \\
\text { alternative }\end{array}$ & $\mathrm{t}$ & $\mathrm{p}$-val two-tail & $\mathrm{p}$-val one tail \\
\hline 1 & 1659 & 3822 & 0.0021 & 1658 & -8.2551 & 0.0001 & 0.0001 \\
2 & 1249 & 3160 & 0.0024 & 1248 & -7.7713 & 0.0001 & 0.0001 \\
3 & 920 & 2640 & 0.0028 & 919 & -6.8482 & 0.0001 & 0.0001 \\
4 & 686 & 2109 & 0.0032 & 685 & -6.3010 & 0.0001 & 0.0001 \\
5 & 508 & 1638 & 0.0035 & 507 & -6.6890 & 0.0001 & 0.0001 \\
6 & 356 & 1261 & 0.0043 & 355 & -5.4885 & 0.0001 & 0.0001 \\
7 & 260 & 957 & 0.0052 & 259 & -5.6257 & 0.0001 & 0.0001 \\
8 & 200 & 731 & 0.0058 & 199 & -5.3803 & 0.0001 & 0.0001 \\
9 & 131 & 552 & 0.0064 & 130 & -4.2380 & 0.0001 & 0.0001 \\
10 & 88 & 431 & 0.0073 & 87 & -3.5553 & 0.0006 & 0.0003 \\
\hline
\end{tabular}

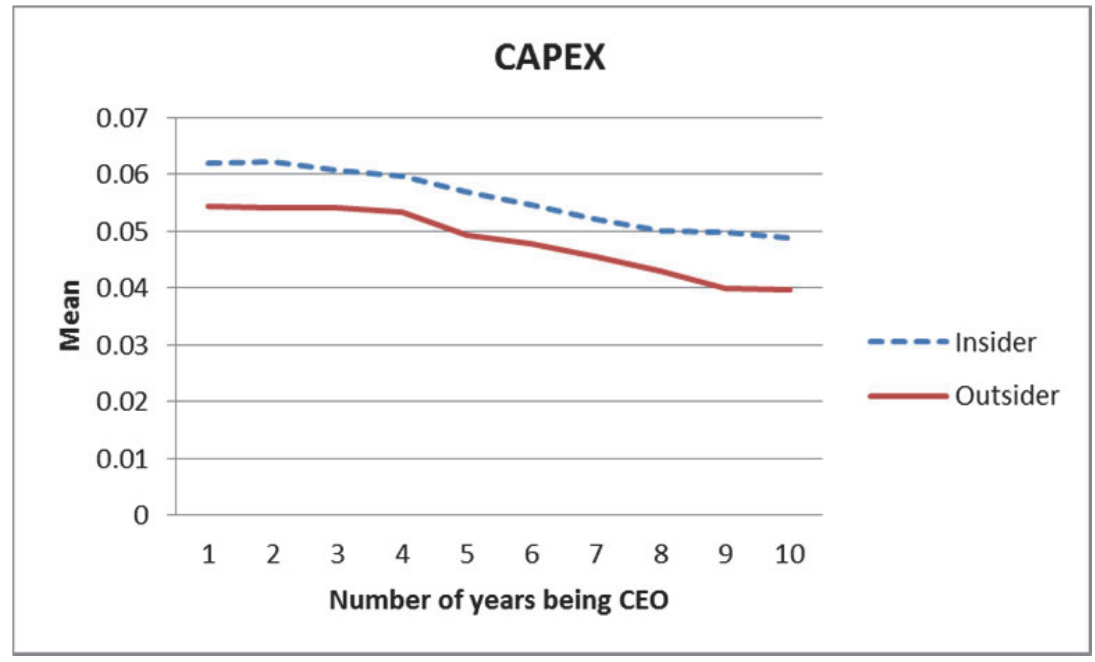


Panel C: Book Leverage.

The null hypothesis used is $\mathrm{H}_{0}: \overline{X_{\text {out }}}=\overline{X_{\text {ln }}}$, for the two-tail test and $\mathrm{H}_{0}: \overline{X_{\text {out }}} \geq \overline{X_{\text {ln }}}$ for the one-tail test, where $\bar{X}_{\text {out }}$ and $\overline{X_{l n}}$ are the mean of book leverage of outsider replacement CEOs and insider replacement CEOs respectively.

\begin{tabular}{l|lllllll}
\hline Year & Outsider & Insider & SE & $\begin{array}{l}\text { DF } \\
\text { alternative }\end{array}$ & $\mathrm{t}$ & p-val two-tail & p-val one tail \\
\hline 1 & 1659 & 3822 & 0.0021 & 1658 & -8.2551 & 0.0001 & 0.0001 \\
2 & 1249 & 3160 & 0.0024 & 1248 & -7.7713 & 0.0001 & 0.0001 \\
3 & 920 & 2640 & 0.0028 & 919 & -6.8482 & 0.0001 & 0.0001 \\
4 & 686 & 2109 & 0.0032 & 685 & -6.3010 & 0.0001 & 0.0001 \\
5 & 508 & 1638 & 0.0035 & 507 & -6.6890 & 0.0001 & 0.0001 \\
6 & 356 & 1261 & 0.0043 & 355 & -5.4885 & 0.0001 & 0.0001 \\
7 & 260 & 957 & 0.0052 & 259 & -5.6257 & 0.0001 & 0.0001 \\
8 & 200 & 731 & 0.0058 & 199 & -5.3803 & 0.0001 & 0.0001 \\
9 & 131 & 552 & 0.0064 & 130 & -4.2380 & 0.0001 & 0.0001 \\
10 & 88 & 431 & 0.0073 & 87 & -3.5553 & 0.0006 & 0.0003 \\
\hline
\end{tabular}

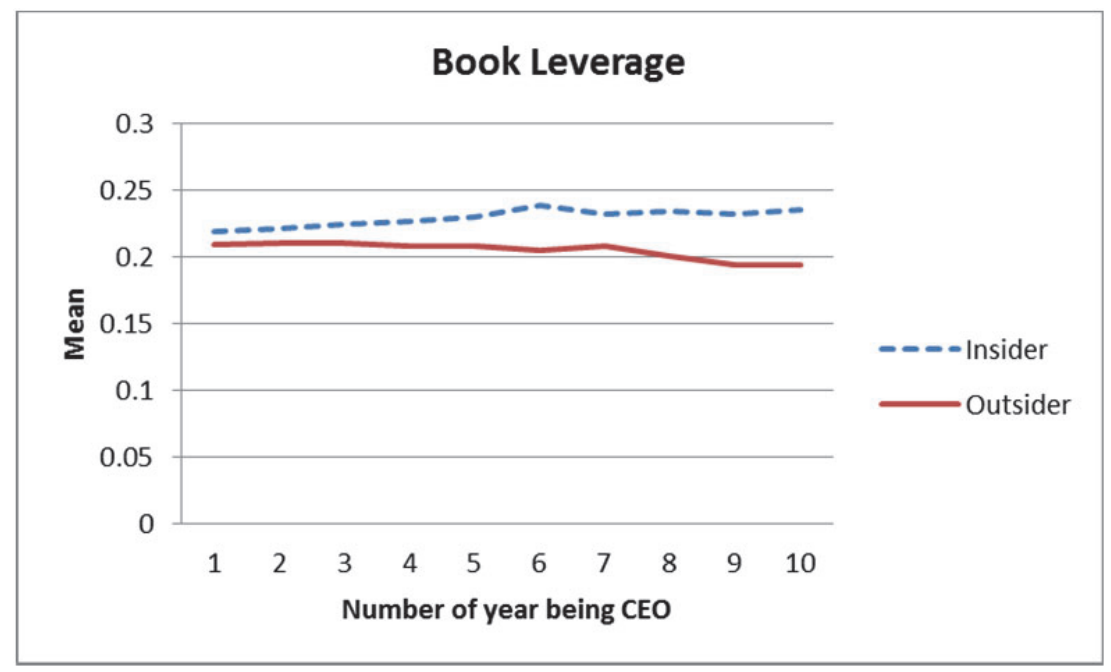


Panel D: Market Leverage.

The null hypothesis used is $\mathrm{H}_{0}: \overline{X_{\text {out }}}=\overline{X_{\text {ln }}}$, for the two-tail test and $\mathrm{H}_{0}: \overline{X_{\text {out }}} \geq \overline{X_{\text {ln }}}$ for the one-tail test, where $\bar{X}_{\text {out }}$ and $\overline{X_{l n}}$ are the mean of market leverage of outsider replacement CEOs and insider replacement CEOs respectively.

\begin{tabular}{l|lllllll}
\hline Year & Outsider & Insider & SE & $\begin{array}{l}\text { DF } \\
\text { alternative }\end{array}$ & $\mathrm{t}$ & $\mathrm{p}$-val two-tail & $\mathrm{p}$-val one tail \\
\hline 1 & 1659 & 3822 & 0.0021 & 1658 & -8.2551 & 0.0001 & 0.0001 \\
2 & 1249 & 3160 & 0.0024 & 1248 & -7.7713 & 0.0001 & 0.0001 \\
3 & 920 & 2640 & 0.0028 & 919 & -6.8482 & 0.0001 & 0.0001 \\
4 & 686 & 2109 & 0.0032 & 685 & -6.3010 & 0.0001 & 0.0001 \\
5 & 508 & 1638 & 0.0035 & 507 & -6.6890 & 0.0001 & 0.0001 \\
6 & 356 & 1261 & 0.0043 & 355 & -5.4885 & 0.0001 & 0.0001 \\
7 & 260 & 957 & 0.0052 & 259 & -5.6257 & 0.0001 & 0.0001 \\
8 & 200 & 731 & 0.0058 & 199 & -5.3803 & 0.0001 & 0.0001 \\
9 & 131 & 552 & 0.0064 & 130 & -4.2380 & 0.0001 & 0.0001 \\
10 & 88 & 431 & 0.0073 & 87 & -3.5553 & 0.0006 & 0.0003 \\
\hline
\end{tabular}

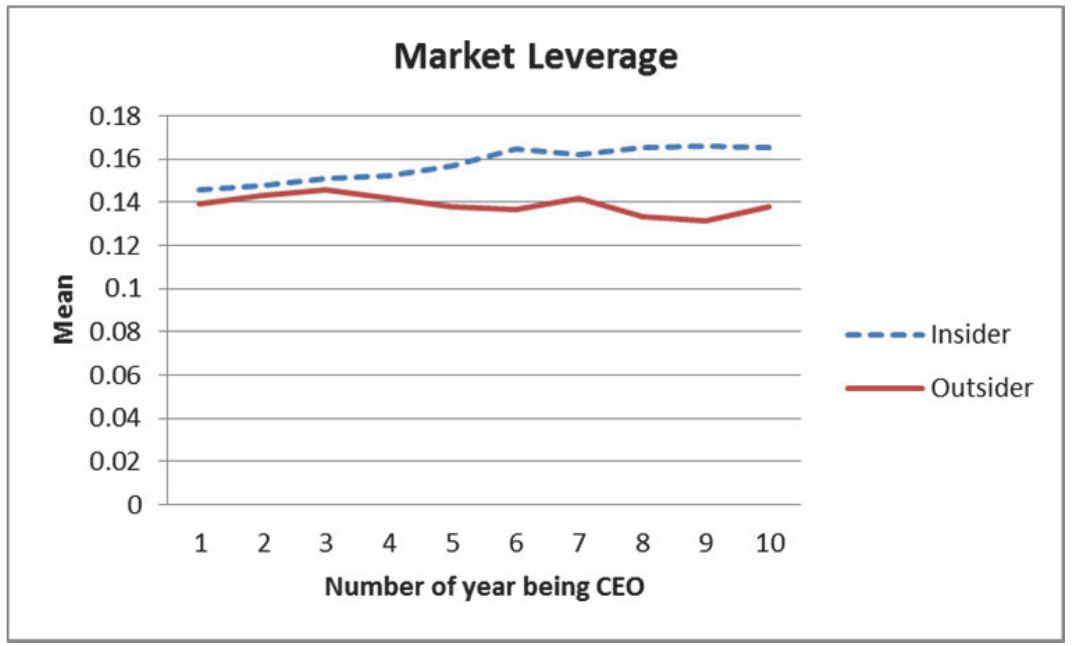


We examine whether the difference between average risk-taking implemented by outsider and insider CEOs is statistically different from zero. From table 2, we find results that are consistent with our expectation that the average of risk-taking measures implemented by outsider CEOs is statistically different from that implemented by insider CEOs and the difference is statistically significant at $1 \%$ level in every year for the ten years after the CEO turnover. We also examine the hypothesis that outsider CEOs are more of a risk-taker than insider CEOs and again we also find convincing evidence that outsider CEOs implement more risky investment decisions than insider CEOs (indicated by higher R\&D and lower capital expenditures) and that the results are statistically significant at $1 \%$ level. Interestingly, we find that the average leverage (measured either by book value of leverage or market value of leverage) is lower for outsider CEOs than insider CEOs. We discuss this specific finding about leverage in the univariate analysis section.

\section{Univariate Analysis}

We present the pairwise correlation table in table 3. We find that the CEO origin dummy is positively correlated with R\&D and negatively correlated with capital expenditures. These results both imply that outsider CEOs take more risk than insider CEOs. Interestingly, we find that there is a negative correlation between the CEO origin dummy and measure of leverage (measured either by book value of leverage or by market value of leverage) and this negative correlation is significant at $5 \%$ level. The negative sign of the correlation is the opposite of what we expect from the correlation between CEO origin dummy and leverage and this negative correlation is consistent with the finding that the average leverage ratio implemented by outsider CEOs is lower than that of the insider CEOs in the previous section. As unexpected as the negative correlation is, this particular finding is in line with the finding of Frank and Goyal (2009) who argue that in the event that there is a forced CEO turnover, the company leverage will be elevated one year before the turnover and outsider new CEO will reduce the elevated level of leverage by more than insider new CEOs will. Combining the finding of Frank and Goyal (2009) with the finding that financially troubled firms are more likely to hire outsider CEOs to change the direction of the firm, we find an interesting result that although outsider CEOs take more risks than insider CEOs, they increase the risk of the company through higher R\&D expenditure and lower capital expenditure investment and not through higher leverage. This finding contributes to the literature of corporate risk-taking that although outsider CEOs are more of a risk taker, they increase risk through investing more in R\&D and less in capital expenditures but not through higher leverage. ${ }^{6}$

To control for other CEO personal and compensation variables as well as for firm characteristic variables, we examine the role of a CEO career origin on corporate risk-taking utilizing the multivariate analysis

\section{Multivariate Analysis}

We run multivariate regression analysis to examine whether and how a CEO career origin affects the corporate risk-taking while controlling for CEO compensation sensitivity variables (such as delta and vega) ${ }^{7}$ and for firm characteristic variables. The regressions are as follows:

$$
\begin{aligned}
& R \& D_{i, t}=\alpha+\lambda(C E O \text { career origin dummy })_{i, t-1}+\beta(C E O \text { personal characteristc })_{i, t-1} \\
& +\gamma(C E O \text { pay characteristic })_{i, t-1}+\theta(\text { Firm Characteristic })_{i, t-1}+\varepsilon_{i, t} \\
& \text { CAPEX }_{i, t}=\alpha+\lambda(\text { CEO career origin dummy })_{i, t-1}+\beta(\text { CEO personal characteristc })_{i, t-1} \\
& +\gamma(\text { CEO pay characteristic })_{i, t-1}+\theta(\text { Firm Characteristic })_{i, t-1}+\varepsilon_{i, t} \\
& B_{k L e v}, t=\alpha+\lambda(C E O \text { career origin dummy })_{i, t-1}+\beta(\text { CEO personal characteristc })_{i, t-1}
\end{aligned}
$$

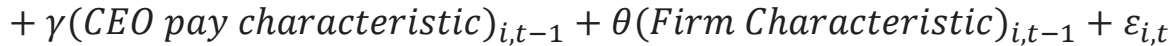

$$
\begin{aligned}
& \text { MktLev }_{i, t}=\alpha+\lambda(\text { CEO career origin dummy })_{i, t-1}+\beta(\text { CEO personal characteristc })_{i, t-1} \\
& \left.+\gamma(\text { CEO pay characteristic })_{i, t-1}+\theta \text { (Firm Characteristic }\right)_{i, t-1}+\varepsilon_{i, t}
\end{aligned}
$$


In table 4 column (1), we start with the pooled OLS regression using firm fixed effects. We find that all coefficients are consistent with the corporate risk-taking literature. Then, in column (2) we add the CEO career origin dummy into the regression. We find that the CEO origin effect is statistically significant at $1 \%$ level and this result implies that outsider CEOs make more R\&D investment than insider CEOs. In column (3), we rerun the regression using the clustered standard errors by year and by industry and we still find similar results.

In table 5, we examine how the CEO career origin affects the firm's capital expenditure. We find that outsider CEOs invest less in capital expenditure than insider CEOs. This finding is consistent even after we cluster the standard errors by year and by industry.

In table 6 and 7, we find that outsider CEOs use more leverage than insider CEOs. This finding is consistent with the findings we find from the mean difference test and the univariate analysis. It simply means that outsider CEOs use less leverage in the first several years in their tenure and increase the leverage over time.

\section{CONCLUSIONS}

In this paper, we examine how a CEO career origin affects firm risk-taking and whether the reason the board of directors hires their new CEOs from outside of the firm is because of the new CEO's personal risk-taking preference. We find that outsider CEOs make more risky investment decisions (invest more in R\&D, invest less in capital expenditures, and use more leverage) than insider CEOs. One can argue that outsider CEOs take more risks because of their compensation structure has more equitybased portion and that kind of compensation structure encourages CEOs to take more risk. However, after controlling for compensation sensitivity variables such as delta and vega, we find that outsider CEOs are still significantly more risk-taking than insider CEOs. Our results suggest that outsider CEOs are more risk-taking than insider CEOs and the board of directors, despite the higher costs of hiring outsider CEOs, may very well hire outsider CEOs because of the risk-taking reason. Our results also suggest that the CEO compensation structure difference (between outsider and insider CEOs) is not the reason why outsider CEOs take more risk than insider CEOs.

In addition to examining the relation between CEO career origin and the level of the firm risk-taking, we also examine the relation between CEO career origin and the change in the firm risk-taking years after the CEO turnover. We find that on average, outsider CEOs increase the normalized R\&D ratio by $1.77 \%$ in the four year period (from one year before the CEO turnover to three years after the turnover), while the insider CEOs increase the normalized R\&D ratio only by $0.63 \%$ during the same time period. This also helps explain why the board is more likely to hire outsider CEOs when the firms struggle.

Our paper contributes to the CEO turnover and corporate risk-taking literature in three different ways. First, we show that a CEO career origin matters in corporate risk-taking and we extend the literature on the relation between CEO personal characteristic and corporate risk-taking. Second, we provide an alternative explanation as to why firms hire more outsider CEOs now than before. We argue that outsider CEOs do not make more risky investment decisions because of their compensation structure but they make more risky investment decisions because they are more risk-taking than insider CEOs and that may be the reason firms hire more outsider CEOs now than before. Third, we find mixed results about the relation between a CEO career origin and corporate risk-taking. Interestingly outsider CEOs increase the risk of the firm by investing more in R\&D and less in capital expenditure, but not through increased leverage.

\section{ACKNOWLEDGEMENT}

We acknowledge helpful comments and data from Lalita Naveen and Dirk Jenter. All remaining errors are our own. 


\section{ENDNOTES}

1. Datta, Iskandar-Datta, and Raman (2001); Sanders (2001); Eisenmann (2002); Low (2009) find that equitybased executive compensation does influence the firm's risk-taking positively.

2. They find that external hires jump from $15 \%$ in 1970 s to more than $25 \%$ in 2000 s.

3. Ferris, Wei, and Zhang (2007) report that the performance difference between outsider CEOs and insider CEOs

4. It is widely documented that outsider CEOs are paid more both in cash compensation and in the equitybased compensation

5. Execucomp provides annual compensation data for the top 5 highest paid executives in S\&P 500, S\&P Midcap 400, and S\&P Smallcap 600 firms.

6. In corporate risk-taking literature, higher risk is usually indicated by higher R\&D, lower capital expenditure, and higher leverage (see Coles, Daniel, and Naveen (2006)).

7. Coles, Daniel, and Naveen find that CEOs with higher delta and vega are more likely to implement more risky investment policy.

\section{REFERENCES}

Bebchuk, L., \& Grinstein, Y. (2005). The growth of executive pay. Oxford Review of Economic Policy, 21, 283-303.

Bertrand, M., \& Schoar, A. (2003). Managing with style: The effect of managers on firm policies. Quarterly Journal of Economics, 118, 1169-1208.

Cain, M.D., \& McKeon, S.B. (2011). Cleared for takeoff? CEO personal risk-taking and corporate policies. Working paper.

Coles, J.L., Daniel, N.D., \& Naveen, L. (2006). Managerial incentives and risk-taking. Journal of Financial Economics, 79, 431-468.

Core, J., \& Guay, W. (2002). Estimating the value of employee stock option portfolio and their sensitivities to price and volatility. Journal of Accounting Research, 40, 613-630.

Cronqvist, H., Makhija, A.K., \& Yonker, S.E. (2012). Behavioral consistency in corporate finance: CEO personal and corporate leverage. Journal of Financial Economics, 103, 20-40.

Datta, S., Iskandar-Datta, M., \& Raman, K. (2001). Executive compensation and corporate acquisition decisions. Journal of Finance, 56, 2299-2336.

Eisenmann, T.R. (2002). The effects of CEO equity ownership and firm diversification on risk taking. Strategic Management Journal, 23, 513-534.

Ferris, S.P., Wei, Z., \& Zhang, S. (2007). CEO succession, incentives and firm performance: Insiders versus outsiders. Working paper.

Frank, M.Z., \& Goyal, V.K. (2009). Corporate leverage: how much do managers really matter? Working paper.

Galasso, A., \& Simcoe, T.S. (2011). CEO overconfidence and innovation. Working paper.

Guay, W. (1999). The sensitivity of CEO wealth to equity risk: An analysis of the magnitude and determinants. Journal of Financial Economics, 53, 43-71.

Huson, M.R., Malatesta, P.H., \& Parrino, R. (2004). Managerial succession and firm performance. Journal of Financial Economics, 74, 237-275.

Low, A. (2009). Managerial risk-taking behavior and equity-based compensation. Journal of Financial Economics, 92, 470-490.

Malmendier, U., \& Tate, G. (2005). CEO overconfidence and corporate investments. Journal of Finance, 60, 2661-2700.

Murphy, K. (2002). Explaining executive compensation: managerial power vs. perceived cost of stock options. University of Chicago Law Review, 69, 847-863.

Murphy, K., \& Zabojnik, J. (2007). Managerial capital and the market for CEOs. Working paper.

Sanders, W.G. (2001). Behavioral responses of CEOs to stock ownership and stock option pay. Academy of Management Journal, 44, 477-492. 
Wade, J.B., Porac, J.F., Pollock, T.G., \& Graffin, S.D. (2006). The burden of celebrity: the impact of CEO certification contests on CEO pay and performance. Academy of Management Journal, 49, 643-6630.

Wang, L. (2009). CEO employment history and risk-taking in firm policies. Working paper.

Zhang, Y., \& Rajagopalan, N. (2010). Once an outsider, always an outsider? CEO origin, strategic change, and firm performance. Strategic Management Journal, 31, 334-346. 
む)

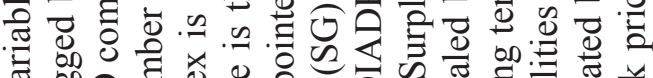

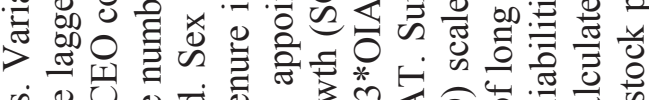

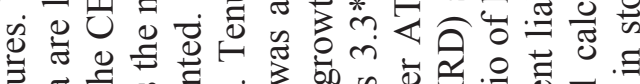

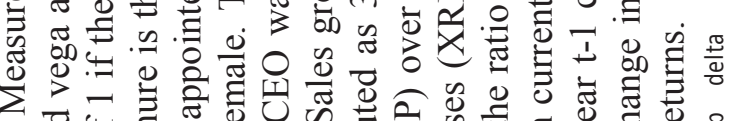

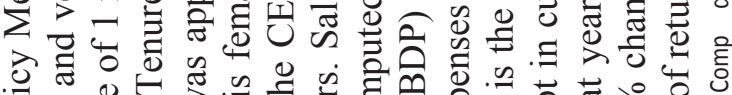

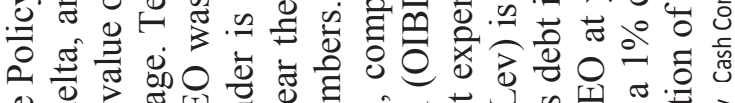
\&

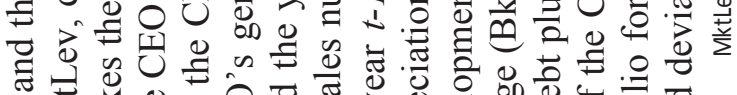

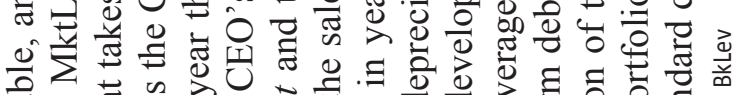

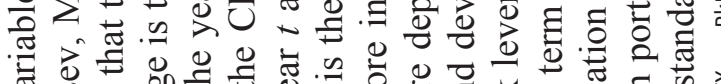

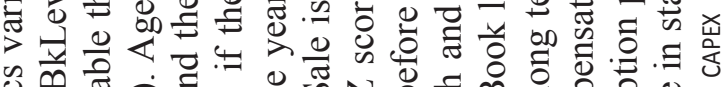

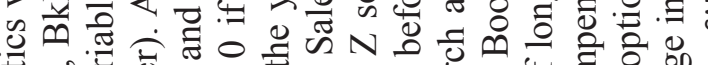

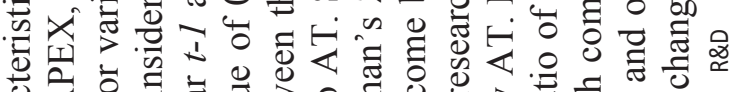

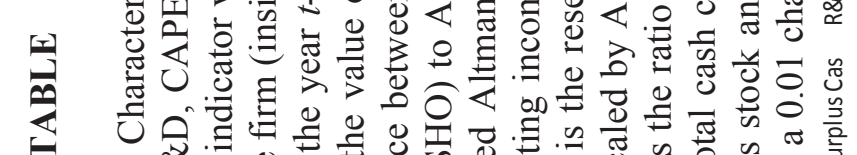

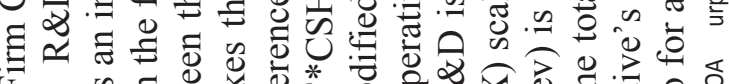

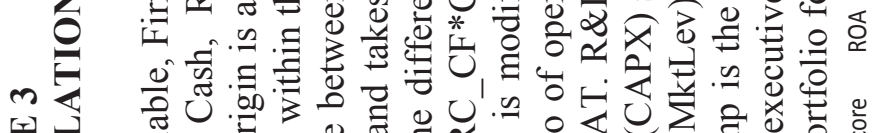

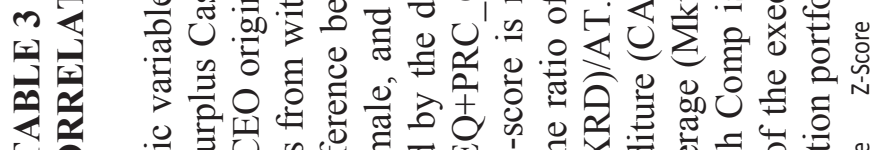

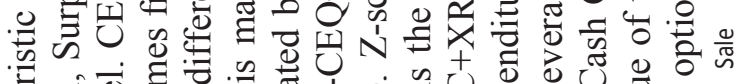

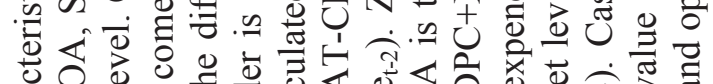

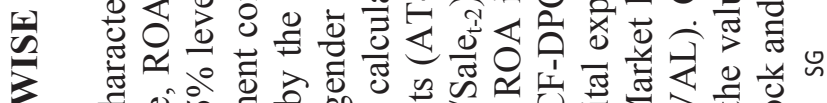

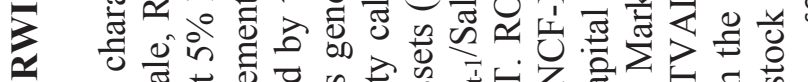

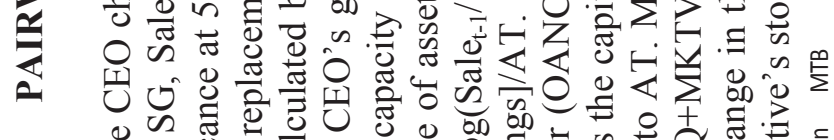

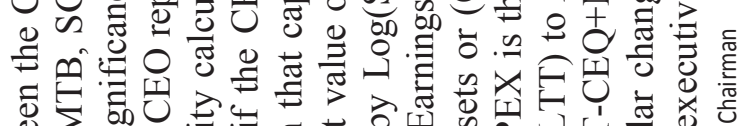

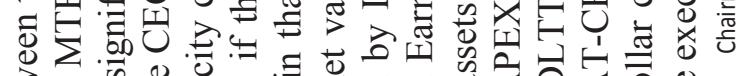

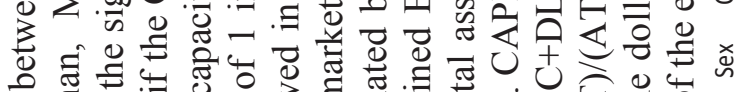

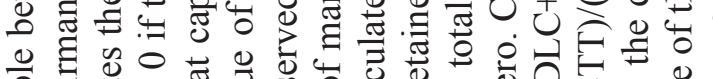

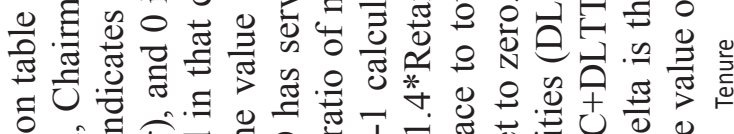

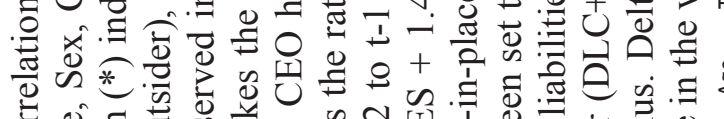

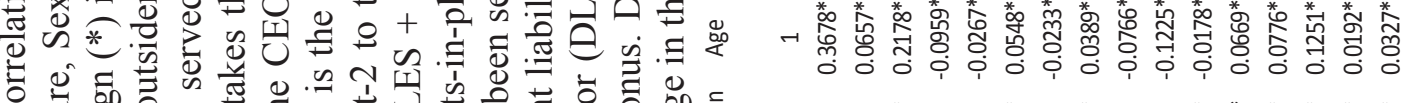

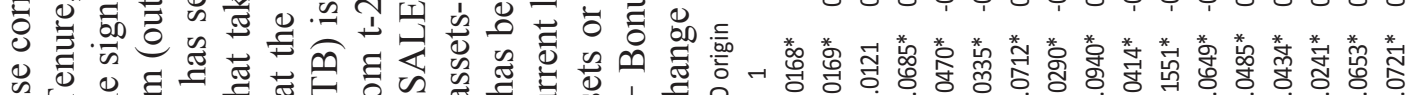

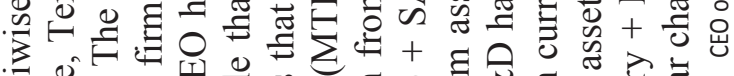

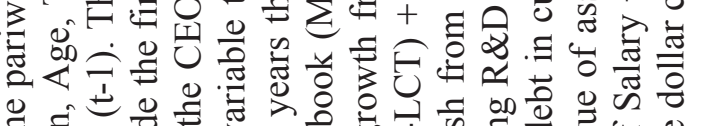

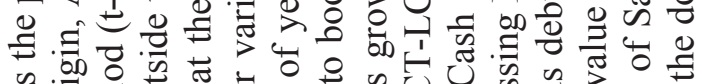

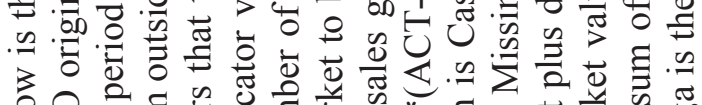
空

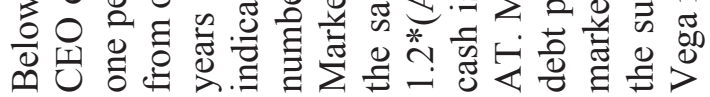




\section{TABLE 4 \\ R\&D REGRESSION}

R\&D is the research and development expenses (XRD) scaled by AT. Missing R\&D has been set to zero. CEO Career Origin Dummy is an indicator variable that takes the value of 1 for outsider CEO and 0 for insider CEO. CEO personal characteristic, CEO pay characteristic, and Firm characteristic are explained in Appendix A. * is 10\% significance level, ** is 5\% significance level, and *** is $1 \%$ significance level.

\begin{tabular}{|c|c|c|c|}
\hline \multirow{2}{*}{ Variable } & Pooled OLS & Pooled OLS & Clustered SE by Year \\
\hline & $(1)$ & (2) & (3) \\
\hline CEO Origin & & $\begin{array}{l}0.005^{* * *} \\
(4.26)\end{array}$ & $\begin{array}{l}0.005 * * * \\
(3.71)\end{array}$ \\
\hline CEO Characteristic & & & \\
\hline Age & $\begin{array}{l}0.0002 * * \\
(2.07)\end{array}$ & $\begin{array}{l}0.0001 * \\
(1.82)\end{array}$ & $\begin{array}{l}0.0001 \\
(1.29)\end{array}$ \\
\hline Tenure & $\begin{array}{l}-0.0004 * * * \\
-(5.05)\end{array}$ & $\begin{array}{l}-0.0004 * * * \\
-(4.98)\end{array}$ & $\begin{array}{l}-0.0004 * * * \\
-(4.45)\end{array}$ \\
\hline Sex & $\begin{array}{l}0.0134 * * * \\
(3.68)\end{array}$ & $\begin{array}{l}0.0133^{* * * *} \\
(3.63)\end{array}$ & $\begin{array}{l}0.01326883 * * * \\
(4.58)\end{array}$ \\
\hline CEO Pay Characteristic & & & \\
\hline Delta & $\begin{array}{l}-0.0012 * * * \\
-(2.55)\end{array}$ & $\begin{array}{l}-0.0011 * * * \\
-(2.45)\end{array}$ & $\begin{array}{l}-0.0011 * * * \\
-(2.9)\end{array}$ \\
\hline Vega & $\begin{array}{l}0.0044^{* * * *} \\
(3.78)\end{array}$ & $\begin{array}{l}0.0045^{* * *} \\
(3.89)\end{array}$ & $\begin{array}{l}0.0045^{* * *} \\
(2.38)\end{array}$ \\
\hline Cash Compensation & $\begin{array}{l}0.0027 * * * \\
(4.25)\end{array}$ & $\begin{array}{l}0.0027 * * * \\
(4.14)\end{array}$ & $\begin{array}{l}0.0027 * * * \\
(2.62)\end{array}$ \\
\hline Firm Characteristic & & & \\
\hline Market to Book & $\begin{array}{l}0.0112 * * * \\
(27.55)\end{array}$ & $\begin{array}{l}0.0112 * * * \\
(27.59)\end{array}$ & $\begin{array}{l}0.0112^{* * *} \\
(6.68)\end{array}$ \\
\hline Sales Growth & $\begin{array}{l}0.0018^{* * *} \\
(3.53)\end{array}$ & $\begin{array}{l}0.0018^{* * *} \\
(3.37)\end{array}$ & $\begin{array}{l}0.0018^{* * *} \\
(2.16)\end{array}$ \\
\hline Log(Sales) & $\begin{array}{l}-0.0051 * * * \\
-(12.63)\end{array}$ & $\begin{array}{l}-0.0049 * * * \\
-(12.29)\end{array}$ & $\begin{array}{l}-0.0049 * * * \\
-(8.47)\end{array}$ \\
\hline ROA & $\begin{array}{l}-0.2199 * * * \\
-(42.26)\end{array}$ & $\begin{array}{l}-0.2193 * * * \\
-(42.16)\end{array}$ & $\begin{array}{l}-0.2193 * * * \\
-(10.76)\end{array}$ \\
\hline Surplus Cash & $\begin{array}{l}0.1485^{* * *} \\
(41.45)\end{array}$ & $\begin{array}{l}0.1468^{* * *} \\
(40.75)\end{array}$ & $\begin{array}{l}0.1468^{* * * *} \\
(12.81)\end{array}$ \\
\hline Constant & $\begin{array}{l}0.0204 * * * \\
(3.15)\end{array}$ & $\begin{array}{l}0.02 * * * \\
(3.1)\end{array}$ & $\begin{array}{l}0.02 * * * \\
(2.31)\end{array}$ \\
\hline 2-digit SIC controls & Yes & Yes & Yes \\
\hline Observations & 14703 & 14703 & 14703 \\
\hline Adjusted $\mathrm{R}^{2}$ & 0.3808 & 0.3815 & 0.382 \\
\hline
\end{tabular}




\section{TABLE 5 \\ CAPEX REGRESSION}

CAPEX is the capital expenditure (CAPX) scaled by AT. CEO Career Origin Dummy is an indicator variable that takes the value of 1 for outsider $\mathrm{CEO}$ and 0 for insider CEO. CEO personal characteristic, CEO pay characteristic, and Firm characteristic are explained in Appendix A. * is 10\% significance level, $* *$ is $5 \%$ significance level, and *** is $1 \%$ significance level.

\begin{tabular}{|c|c|c|c|}
\hline \multirow{2}{*}{ Variable } & Pooled OLS & Pooled OLS & Clustered SE by Year \\
\hline & $(1)$ & $(2)$ & (3) \\
\hline CEO Origin & & $\begin{array}{l}-0.0061 * * * \\
-(5.86)\end{array}$ & $\begin{array}{l}-0.0061 * * * \\
-(6.41)\end{array}$ \\
\hline \multicolumn{4}{|l|}{ CEO Characteristic } \\
\hline Age & $\begin{array}{l}-0.0002 * * * \\
-(3.11)\end{array}$ & $\begin{array}{l}-0.0002 * * * \\
-(2.77)\end{array}$ & $\begin{array}{l}-0.0002 * * * \\
-(3.29)\end{array}$ \\
\hline Tenure & $\begin{array}{l}0.0003 \\
(3.68)\end{array}$ & $\begin{array}{l}0.0002 * * * \\
(3.59)\end{array}$ & $\begin{array}{l}0.0002 * * * \\
(4.3)\end{array}$ \\
\hline Sex & $\begin{array}{l}0.0094 * * * \\
(2.94)\end{array}$ & $\begin{array}{l}0.0096^{* * * *} \\
(3.01)\end{array}$ & $\begin{array}{l}0.0096^{* * * *} \\
(2.89)\end{array}$ \\
\hline \multicolumn{4}{|l|}{ CEO Pay Characteristic } \\
\hline Delta & $\begin{array}{l}0.0021 * * * \\
(5.24)\end{array}$ & $\begin{array}{l}0.0021 * * * \\
(5.1)\end{array}$ & $\begin{array}{l}0.0021 * * * \\
(3.46)\end{array}$ \\
\hline Vega & $\begin{array}{l}-0.0063 \\
-(6.18)\end{array}$ & $\begin{array}{l}-0.0065 \\
-(6.34)\end{array}$ & $\begin{array}{l}-0.0065 \\
-(5.01)\end{array}$ \\
\hline Cash Compensation & $\begin{array}{l}-0.0009 * * \\
-(1.67)\end{array}$ & $\begin{array}{l}-0.0009 * \\
-(1.51)\end{array}$ & $\begin{array}{l}-0.0009^{*} \\
-(1.06)\end{array}$ \\
\hline \multicolumn{4}{|l|}{ Firm Characteristic } \\
\hline Market to Book & $\begin{array}{l}0.0013^{* * * *} \\
(3.75)\end{array}$ & $\begin{array}{l}0.0013^{* * *} \\
(3.72)\end{array}$ & $\begin{array}{l}0.0013^{* * *} \\
(1.64)\end{array}$ \\
\hline Sales Growth & $\begin{array}{l}-0.0014 * * * \\
-(3.15)\end{array}$ & $\begin{array}{l}-0.0013 * * * \\
-(2.92)\end{array}$ & $\begin{array}{l}-0.0013 \\
-(1.4)\end{array}$ \\
\hline $\log ($ Sales $)$ & $\begin{array}{l}-0.0046 * * * \\
-(13.19)\end{array}$ & $\begin{array}{l}-0.0047 * * * \\
-(13.59)\end{array}$ & $\begin{array}{l}-0.0047 * * * \\
-(7.88)\end{array}$ \\
\hline ROA & $\begin{array}{l}0.1285^{* * *} \\
(28.34)\end{array}$ & $\begin{array}{l}0.1278^{* * *} \\
(28.21)\end{array}$ & $\begin{array}{l}0.1278^{* * * *} \\
(9.63)\end{array}$ \\
\hline Surplus Cash & $\begin{array}{l}-0.0478 * * * \\
-(15.3)\end{array}$ & $\begin{array}{l}-0.0457 * * * \\
-(14.57)\end{array}$ & $\begin{array}{l}-0.0457 * * * \\
-(7.94)\end{array}$ \\
\hline Constant & $\begin{array}{l}0.0815^{* * * *} \\
(14.44)\end{array}$ & $\begin{array}{l}0.0819^{* * * *} \\
(14.53)\end{array}$ & $\begin{array}{l}0.0819 * * * \\
(12.72)\end{array}$ \\
\hline 2-digit SIC controls & Yes & Yes & Yes \\
\hline Observations & 14703 & 14703 & 14703 \\
\hline Adjusted $\mathrm{R}^{2}$ & 0.0975 & 0.0995 & 0.1003 \\
\hline
\end{tabular}




\section{TABLE 6 \\ BOOK LEVERAGE REGRESSION}

Book leverage is the ratio of long term debt plus debt in current liabilities (DLC+DLTT) to AT in year t. CEO Career Origin Dummy is an indicator variable that takes the value of 1 for outsider CEO and 0 for insider CEO. CEO personal characteristic, CEO pay characteristic, and Firm characteristic are explained in Appendix A. * is 10\% significance level, ** is 5\% significance level, and *** is $1 \%$ significance level.

\begin{tabular}{|c|c|c|c|}
\hline \multirow{2}{*}{ Variable } & Pooled OLS & Pooled OLS & Clustered SE by Year \\
\hline & $(1)$ & (2) & (3) \\
\hline CEO Origin & & $\begin{array}{l}0.0072 * * \\
(2.06)\end{array}$ & $\begin{array}{l}0.0051 * * * \\
(3.71)\end{array}$ \\
\hline \multicolumn{4}{|l|}{ CEO Characteristic } \\
\hline Age & $\begin{array}{l}-0.0000 \\
-(0.15)\end{array}$ & $\begin{array}{l}-0.0001 \\
-(0.27)\end{array}$ & $\begin{array}{l}0.0001 \\
(1.29)\end{array}$ \\
\hline Tenure & $\begin{array}{l}-0.0001 \\
-0.48\end{array}$ & $\begin{array}{l}-0.0001 \\
-0.45\end{array}$ & $\begin{array}{l}-0.0004 * * * \\
-4.45\end{array}$ \\
\hline Sex & $\begin{array}{l}0.0209 * \\
(1.93)\end{array}$ & $\begin{array}{l}0.0206^{*} \\
(1.9)\end{array}$ & $\begin{array}{l}0.0133^{* * *} \\
(4.58)\end{array}$ \\
\hline \multicolumn{4}{|l|}{ CEO Pay Characteristic } \\
\hline Delta & $\begin{array}{l}-0.0021 \\
-(1.54)\end{array}$ & $\begin{array}{l}-0.002 \\
-(1.49)\end{array}$ & $\begin{array}{l}-0.0011 * * * \\
-(2.9)\end{array}$ \\
\hline Vega & $\begin{array}{l}0.0029 \\
0.84\end{array}$ & $\begin{array}{l}0.0031 \\
0.89\end{array}$ & $\begin{array}{l}0.0045^{* * *} \\
2.38\end{array}$ \\
\hline Cash Compensation & $\begin{array}{l}0.0091 * * * \\
(4.66)\end{array}$ & $\begin{array}{l}0.0089 * * * \\
(4.6)\end{array}$ & $\begin{array}{l}0.0027 * * * \\
(2.62)\end{array}$ \\
\hline \multicolumn{4}{|l|}{ Firm Characteristic } \\
\hline Market to Book & $\begin{array}{l}0.0062^{* * *} \\
(5.21)\end{array}$ & $\begin{array}{l}0.0063 * * * \\
(5.23)\end{array}$ & $\begin{array}{l}0.0112^{* * *} \\
(6.68)\end{array}$ \\
\hline Sales Growth & $\begin{array}{l}-0.0004 \\
-(0.24)\end{array}$ & $\begin{array}{l}-0.0005 \\
-(0.32)\end{array}$ & $\begin{array}{l}0.0018 * * \\
(2.16)\end{array}$ \\
\hline $\log ($ Sales $)$ & $\begin{array}{l}0.0059 * * * \\
(4.96)\end{array}$ & $\begin{array}{l}0.006^{* * * *} \\
(5.1)\end{array}$ & $\begin{array}{l}-0.0049 * * * \\
-(8.47)\end{array}$ \\
\hline ROA & $\begin{array}{l}-0.3567 * * * \\
-(23.28)\end{array}$ & $\begin{array}{l}-0.3559 * * * \\
-(23.23)\end{array}$ & $\begin{array}{l}-0.2193 * * * \\
-(10.76)\end{array}$ \\
\hline Surplus Cash & $\begin{array}{l}-0.3875 * * * \\
-(36.69)\end{array}$ & $\begin{array}{l}-0.3899 * * * \\
-(36.7)\end{array}$ & $\begin{array}{l}0.1468^{* * *} \\
(12.81)\end{array}$ \\
\hline Constant & $\begin{array}{l}0.1959 * * * \\
(10.19)\end{array}$ & $\begin{array}{l}0.1956^{* * * *} \\
(10.17)\end{array}$ & $\begin{array}{l}0.02 * * \\
(2.31)\end{array}$ \\
\hline 2-digit SIC controls & Yes & Yes & Yes \\
\hline Observations & 14664 & 14664 & 14664 \\
\hline Adjusted $\mathrm{R}^{2}$ & 0.1371 & 0.1373 & 0.138 \\
\hline
\end{tabular}


TABLE 7

MARKET LEVERAGE REGRESSION

Market leverage is the ratio of long term debt plus debt in current liabilities to market value of assets in year $t$ (DLC+DLTT)/(AT-CEQ+MKTVAL). CEO Career Origin Dummy is an indicator variable that takes the value of 1 for outsider CEO and 0 for insider CEO. CEO personal characteristic, CEO pay characteristic, and Firm characteristic are explained in Appendix A. * is 10\% significance level, ** is 5\% significance level, and $* * *$ is $1 \%$ significance level.

\begin{tabular}{|c|c|c|c|}
\hline \multirow{2}{*}{ Variable } & Pooled OLS & Pooled OLS & Clustered SE by Year \\
\hline & (1) & (2) & (3) \\
\hline CEO Origin & & $\begin{array}{l}0.0061 * * * \\
(2.51)\end{array}$ & $\begin{array}{l}0.0061 * * * \\
(2.53)\end{array}$ \\
\hline CEO Characteristic & & & \\
\hline Age & $\begin{array}{l}-0.0003 \\
-(1.58)\end{array}$ & $\begin{array}{l}-0.0003 * \\
-(1.72)\end{array}$ & $\begin{array}{l}-0.0003 * \\
-(1.72)\end{array}$ \\
\hline Tenure & $\begin{array}{l}0.0004 * * * \\
(2.45)\end{array}$ & $\begin{array}{l}0.0004 * * * \\
(2.49)\end{array}$ & $\begin{array}{l}0.0004 * * * \\
(2.43)\end{array}$ \\
\hline Sex & $\begin{array}{l}0.0077 \\
(1.03)\end{array}$ & $\begin{array}{l}0.0075 \\
(0.99)\end{array}$ & $\begin{array}{l}0.0075 \\
(0.86)\end{array}$ \\
\hline CEO Pay Characteristic & & & \\
\hline Delta & $\begin{array}{l}-0.0009 \\
-(0.89)\end{array}$ & $\begin{array}{l}-0.0008 \\
-(0.83)\end{array}$ & $\begin{array}{l}-0.0008 \\
-(0.61)\end{array}$ \\
\hline Vega & $\begin{array}{l}-0.0052 * * \\
-(2.18)\end{array}$ & $\begin{array}{l}-0.0051 * * \\
-(2.12)\end{array}$ & $\begin{array}{l}-0.0051 \\
-(1.27)\end{array}$ \\
\hline Cash Compensation & $\begin{array}{l}0.0017 \\
(1.26)\end{array}$ & $\begin{array}{l}0.0016 \\
(1.19)\end{array}$ & $\begin{array}{l}0.0016 \\
(0.56)\end{array}$ \\
\hline Firm Characteristic & & & \\
\hline Market to Book & $\begin{array}{l}-0.0188 * * * \\
-(22.63)\end{array}$ & $\begin{array}{l}-0.0188 * * * \\
-(22.62)\end{array}$ & $\begin{array}{l}-0.0188^{* * *} \\
-(10.73)\end{array}$ \\
\hline Sales Growth & $\begin{array}{l}0.0037 * * * \\
(3.5)\end{array}$ & $\begin{array}{l}0.0036^{* * *} \\
(3.4)\end{array}$ & $\begin{array}{l}0.0036^{*} \\
(1.94)\end{array}$ \\
\hline $\log ($ Sales $)$ & $\begin{array}{l}0.0055^{* * *} \\
(6.64)\end{array}$ & $\begin{array}{l}0.0056^{* * *} \\
(6.81)\end{array}$ & $\begin{array}{l}0.0056^{* * * *} \\
(6.16)\end{array}$ \\
\hline ROA & $\begin{array}{l}-0.2524 * * * \\
-(23.66)\end{array}$ & $\begin{array}{l}-0.2517 * * * \\
-(23.59)\end{array}$ & $\begin{array}{l}-0.2517 * * * \\
-(13.23)\end{array}$ \\
\hline Surplus Cash & $\begin{array}{l}-0.2726 * * * \\
-(37.11)\end{array}$ & $\begin{array}{l}-0.2747 * * * \\
-(37.17)\end{array}$ & $\begin{array}{l}-0.2747 * * * \\
-(16.18)\end{array}$ \\
\hline Constant & $\begin{array}{l}0.2201 * * * \\
(16.45)\end{array}$ & $\begin{array}{l}0.2197 * * * \\
(16.43)\end{array}$ & $\begin{array}{l}0.2197 * * * \\
(8.58)\end{array}$ \\
\hline 2-digit SIC controls & Yes & Yes & Yes \\
\hline Observations & 14661 & 14661 & 14661 \\
\hline Adjusted $\mathrm{R}^{2}$ & 0.2464 & 0.2466 & 0.2472 \\
\hline
\end{tabular}

